Barbara Bartkowskal, Tomasz Nawrocki ${ }^{2}$

\title{
Agencja Nieruchomości Rolnych jako powiernik Skarbu Państwa
}

1 stycznia 1992 r. weszła w życie ustawa z dnia 19 października 1991 r. o gospodarowaniu nieruchomościami rolnymi Skarbu Państwa (dalej ustawa), który to akt wprowadził nowe regulacje prawne do zasad gospodarowania mieniem Skarbu Państwa w odniesieniu do nieruchomości rolnych i innych nieruchomości oraz mienia pozostałego po likwidacji państwowych przedsiębiorstw gospodarki rolnej (dalej p.p.g.r.), które w dniu wejścia w życie ustawy znajdowały się w zarządzie państwowych jednostek organizacyjnych, jak również w użytkowaniu wieczystym osób fizycznych i prawnych; w użytkowaniu lub faktycznym władaniu osób fizycznych, osób prawnych oraz innych jednostek organizacyjnych; w Państwowym Funduszu Ziemi $^{3}$. Ustawą ta rozpoczął się proces zmiany struktury własności gruntów rolnych przejętych na rzecz Skarbu Państwa na podstawie dekretu z dnia 6 września 1944 r. o przeprowadzeniu reformy rolnej, jak również na podstawie innych tytułów prawnych (np. za rentę lub emeryturę lub też przejętych przez państwo z innych tytułów na podstawie późniejszych aktów prawnych). Do realizacji celu głównego, jakim było wprowadzenie zmian w zakresie struktury własnościowej nieruchomości rolnych ustawą z dnia 19 października 1991 r., powołano Agencję Własności Rolnej Skarbu Państwa ${ }^{4}$. Agencja została wyposażona w atrybut państwowej osoby prawnej, której Skarb Państwa zgodnie z art. 5 ustawy powierzył wykonywanie prawa własności i innych praw rzeczowych na jego rzecz w stosunku do mienia opisanego wyżej. W konsekwencji, z dniem wejścia w życie ustawy, tj. 1 stycznia 1992 r., Agencja objęła we władanie powierzone składniki mienia Skarbu Państwa (przede wszystkim po zlikwidowanych państwowych przedsiębiorstwach gospodarki rolnej) i wykonuje we własnym imieniu prawa i obowiązki z nimi związane w stosunku do osób trzecich, jak również we własnym imieniu wykonuje związane z tymi składnikami obowiązki publicznoprawne oraz obowiązki wynikające z decy-

Agencja Nieruchomości Rolnych.

Agencja Nieruchomości Rolnych.

Dalsze rozważania odnosić się będą jednak jedynie do nieruchomości rolnych, z pominięciem również kwestii wchodzących w skład Zasobu WRSP lasów.

$4 \quad$ Nazwa zmieniona na Agencję Nieruchomości Rolnych na podstawie art. 18 ust 1 ustawy z dnia 11 kwietnia 2003 r. o kształtowaniu ustroju rolnego, nowa nazwa obowiązuje od 16 lipca 2003 r. 
zji administracyjnych. Agencja przejęła również zobowiązania po p.p.g.r., co uznać należy za odstępstwo od wyrażonej w Kodeksie cywilny zasady, iż państwowe osoby prawne nie odpowiadają za zobowiązania Skarbu Państwa. Ustawa o gospodarowaniu nieruchomościami rolnymi Skarbu Państwa jako akt szczególny modyfikuje więc postanowienie art. $40 \S 1$ Kodeksu cywilnego. Należy podkreślić, że jedną z konsekwencji powierzenia Agencji wykonywania prawa własności i innych praw rzeczowych w stosunku do mienia Skarbu Państwa (wskazanego w art. 1 ustawy) jest wyłączność Agencji w zakresie gospodarowania tym mieniem. Jednocześnie w ustawie wskazano, że mienie nabyte przez Agencję ze środków własnych, w celu zapewnienia funkcjonowania Biura Prezesa i oddziałów terenowych Agencji, stanowi jej własność.

Ustawodawca w art. 5 ustawy przez użycie słowa „powierza” określił rodzaj stosunku prawnego łączącego Skarb Państwa i Agencję.

W doktrynie w zasadzie przyjęto tezę, iż poprzez art. 5 nawiązuje się stosunek powiernictwa pomiędzy Skarbem Państwa a Agencją . Jednak należy mieć na uwadze, że pojęcie ,powiernictwa” - do czasu określenia w art. 5 ustawy - nie było zdefiniowane w prawie polskim. Być może między innymi dlatego, po wejściu w życie ustawy, w doktrynie pojawiły się głosy przeciwników teorii powiernictwa Agencji Nieruchomości Rolnych na mieniu rolnym Skarbu Państwa. Wskazywano bowiem, że wyklucza tę tezę zakres zadań wskazanych w art. 6 ustawy.

Art. 6 powołanej ustawy zakreśla zadania Agencji, wskazując, iż realizuje zadania wynikające z polityki państwa, w szczególności w zakresie:

1) tworzenia oraz poprawy struktury obszarowej gospodarstw rodzinnych;

2) tworzenia warunków sprzyjających racjonalnemu wykorzystaniu potencjału produkcyjnego Zasobu Własności Rolnej Skarbu Państwa;

3) restrukturyzacji oraz prywatyzacji mienia Skarbu Państwa użytkowanego na cele rolnicze;

4) obrotu nieruchomościami i innymi składnikami majątku Skarbu Państwa użytkowanymi na cele rolne;

5) administrowania zasobami majątkowymi Skarbu Państwa przeznaczonymi na cele rolne;

6) zabezpieczenia majątku Skarbu Państwa;

7) inicjowania prac urządzeniowo-rolnych na gruntach Skarbu Państwa oraz popierania organizowania na gruntach Skarbu Państwa prywatnych gospodarstw rolnych; 
Oprócz zadań, o których mowa wyżej, Agencja realizuje również zadania określone odrębnymi przepisami, a w szczególności przepisami o kształtowaniu ustroju rolnego oraz przepisami o realizacji prawa do rekompensaty z tytułu pozostawienia nieruchomości poza obecnymi granicami Rzeczypospolitej Polskiej.

Czy wskazanie zadań Agencji - jak to wskazują głosy odmienne ${ }^{6}$ - wyklucza postawienie tezy, iż Agencja Nieruchomości Rolnych jest powiernikiem Skarbu Państwa? Instytucja powiernictwa bierze początek z prawa rzymskiego - fiducja i była rozumiana jako umowa na podstawie której odbiorca rzeczy, uzyskujący na niej własność, zobowiązuje się przelać z powrotem własność na pozbywcę rzeczy (alienującego) w oznaczonych okolicznościach ${ }^{7}$.

W systemie prawa europejskiego kontynentalnego najbardziej upowszechniła się instytucja powiernictwa w prawie niemieckim, gdzie przyjęła dwie formy ${ }^{8}$. Jedna z nich to prawo (Vollrechtstreuhand), w ramach którego powiernik uzyskuje pełne prawo do powierzonych dóbr, występując w stosunku do osób trzecich jako właściciel lub dysponent prawa, działający we własnym imieniu, ale na rachunek powierzającego ${ }^{9}$. W systemie common law upowszechniły się natomiast trusty.

Na ziemiach polskich do zaborów i w czasie ich trwania powiernictwo to głównie fideikomisy - powiernictwo rodowe, czyli ordynacje rodowe.

Powołany art. 5 ustawy o gospodarowaniu nieruchomościami rolnymi Skarbu Państwa, nie odpowiada żadnej z przedstawionej wyżej konstrukcji powiernictwa, jednak najbliżej mu do konstrukcji występującej w prawie niemieckim.

Zakres praw i obowiązków Agencji Nieruchomości Rolnych jako powiernika Skarbu Państwa budził i budzi wiele wątpliwości. Wynikiem dyskusji jest liczna literatura ale przede wszystkim orzecznictwo sądów powszechnych, Sądu Najwyższego i Naczelnego Sądu Administracyjnego, które zdefiniowały na przestrzeni ostatnich prawie 20 lat zakres stosunku powiernictwa istniejącego pomiędzy Agencją Nieruchomości Rolnych a Skarbem Państwa w następujący sposób:

„Agencja Własności Rolnej Skarbu Państwa, wykonując uprawnienia właściciela na zasadach określonych w ustawie z dnia 19 października 1991 r. o gospodarowaniu nieruchomościami rolnymi Skarbu Państwa oraz o zmianie niektórych ustaw (Dz.U. Nr 107 poz. 464), korzysta z takich samych uprawnień jak każdy inny właściciel w postępowaniu wymiennym (art. 5 ust. 1 ustawy z dnia 26 marca 1982 r. o scalaniu i wymianie gruntów - Dz.U. z 1989 r. Nr 58 poz. 349). Oświadczenie

6 Z. Marmaj, Prywatyzacja PGR, Zielona Góra 1992, s. 14. Przyjęto tezę, że Agencja Nieruchomości Rolnych realizuje jedynie zadania w zakresie polityki rolnej państwa, nie występuje jako powiernik.

W. Osuchowski, Zarys rzymskiego prawa prywatnego, Warszawa 1971, s. 168.

M. Możdżeń-Marcinkowski, Agencja Nieruchomości Rolnych, Kraków 2003, s. 72.

A. Kędzierska-Cieślak, Powiernictwo. Próba określenia konstrukcji prawnej, PiP 1997, s. 51. 
woli w tym zakresie ma charakter cywilnoprawny i nie może być zastąpione rozstrzygnięciem administracyjnym." 10

„Grunty stanowiące własność Skarbu Państwa, przekazane Agencji Własności Rolnej Skarbu Państwa na podstawie ustawy z dnia 19 października 1991 r. o gospodarowaniu nieruchomościami rolnymi Skarbu Państwa oraz o zmianie niektórych ustawy (Dz.U. Nr 107 poz. 464) nie mogą być obciążane świadczeniem publicznoprawnym w postaci opłaty melioracyjnej." ${ }^{11}$

„Skarb Państwa - jak z dotychczasowych rozważań wynika - jest nadal właścicielem nieruchomości, a Agencja Własności Rolnej Skarbu Państwa jako podmiot wykonujący prawo własności i inne prawa rzeczowe na rzecz Skarbu Państwa, dysponujący Zasobem Własności Rolnej Skarbu Państwa i gospodarujący tym Zasobem, powinna być wpisana w dziale drugim księgi wieczystej obok Skarbu Państwa." $" 12$

„Agencja Własności Rolnej Skarbu Państwa wykonując, zgodnie z art. 5 ustawy o gospodarowaniu nieruchomościami rolnymi Skarbu Państwa, prawo własności i inne prawa rzeczowe na rzecz Skarbu Państwa, nie mogłaby zawrzeć umowy o gospodarowaniu na gruntach stanowiących własność Skarbu Państwa, bowiem byłaby to umowa zawarta $\mathrm{z}$ samym sobą. $\mathrm{Z}$ tych samych względów nie jest możliwe uznanie, że Agencja Własności Rolnej Skarbu Państwa korzysta z mienia Skarbu Państwa w sposób bezumowny."13

„Z przepisów art. 5 ustawy z dnia 19 października 1991 r. wynika, że Skarb Państwa powierza Agencji wykonywanie prawa własności i innych praw rzeczowych na jego rzecz w stosunku do mienia, o którym mowa w art. 1 i 2 tej ustawy. Agencja, obejmując we władanie powierzone składniki mienia Skarbu Państwa, wykonuje we własnym imieniu prawa i obowiązki z nimi związane w stosunku do osób trzecich, jak również we własnym imieniu wykonuje związane z tymi składnikami obowiązki publicznoprawne. Agencja wykonuje w imieniu własnym prawa i obowiązki związane z mieniem Skarbu Państwa powierzonym Agencji po zlikwidowanym państwowym przedsiębiorstwie gospodarki rolnej, w tym również prawa i obowiązki wynikające z decyzji administracyjnych."14

„Agencja Własności Rolnej Skarbu Państwa przejmująca majątek oraz wierzytelności i zobowiązania zlikwidowanego przedsiębiorstwa gospodarki rolnej na podstawie art. 13 ust. 2 , art. 14 ust. $3 \mathrm{w}$ zw. $\mathrm{z}$ art. 19 ustawy z dnia 19 października

Wyrok Naczelnego Sądu Administracyjnego z dnia 18 lutego 1994 r. II SA 2410/92, LexPolonica nr 299850, ONSA 1995/2 poz. 67.

Wyrok Naczelnego Sądu Administracyjnego - Ośrodek Zamiejscowy w Lublinie z dnia 7 września 1993 r. SA/Lu $67 / 93$. 
1991 r. o gospodarowaniu nieruchomościami rolnymi Skarbu Państwa oraz o zmianie niektórych ustaw (Dz.U. Nr 107 poz. 464) odpowiada za zobowiązania związane z przekazywanym mieniem do wysokości wartości przejętego mienia." ${ }^{15}$

Agencja jest jedynie instytucją powierniczą Skarbu Państwa, będącą dysponentem prawa przysługującego Skarbowi Państwa ${ }^{16}$. W żaden sposób nie przysługuje jej prawo własności w odniesieniu do powierzonego jej mienia. Skarb Państwa w żaden sposób nie przestaje bowiem być właścicielem powierzonego Agencji mienia. Należy jednak założyć, iż Agencji przysługują względem powierzonego jej mienia wszelkie uprawnienia, które wymienia art. 140 Kodeksu cywilnego. Jej działania jako powiernika stanowią w pewnym sensie ustawową konkretyzację zadań naczelnego organu administracji, jakim jest Minister Rolnictwa i Rozwoju Wsi. Najwłaściwsze wydaje się jednak określenie Agencji jako szczególnej państwowej osoby prawnej, która wykonuje zadania statutowe oraz zadania administracji publicznej, w tym zlecone funkcje administracji publicznej ${ }^{17}$. Agencja, wykonując nałożone na nią przez ustawodawcę zadania, posługuje się więc nie tylko mechanizmami cywilnoprawnymi, ale również administracyjnoprawnymi. 


\section{Agricultural Property Agency - trustee of the State Treasury}

\section{Key words: trust, State Land Fund, Agricultural Property Agency}

On 1st January 1992, the Act on management of agricultural land owned by the State Treasury of 19th October 1991 (hereinafter referred to as the Act) came into effect, which introduced new legal regulations concerning the principles of management of property owned by the State Treasury with reference to agricultural land and other kinds of real estate as well as property left after liquidation of state agricultural enterprises (Polish: państwowe przedsiębiorstwo gospodarki rolnej; hereinafter referred to as ppgr), real estates which on the day of the Act's coming into effect were under management of state organisational units as well as real estate in perpetual usufruct by natural and legal persons; in usufruct or beneficial estate by natural persons, legal persons and other organisational units; in the State Land Fund. With this Act the process of changes in the structure of ownership of agricultural real estate began, real estate that had been taken over to the benefit of the State Treasury on grounds of the decree on agricultural reform of 6th September 1944, as well as on grounds of other legal titles (e.g. in exchange for allowance or retirement pension, or taken over by the state by way of other titles on grounds of later legal acts). In order to accomplish the goal of introducing changes in the structure of ownership of agricultural real estate by virtue of the Act of 19th October 1991, the Agricultural Property of the State Treasury Agency was established. The Agency was invested with attributes of a state-owned legal person, which the State Treasury in accordance with art. 5 of the Act entrusted with exercising ownership rights and other property rights to the benefit of the State Treasury in relation to the aforementioned property. As a consequence whereof, on the day of the Act's coming into effect, i.e. on 1st January 1992, the Agency entered into possession of elements of property of the State Treasury it was entrusted with (above all property left after liquidation of state agricultural enterprises), and exercises on its own behalf the rights and obligations related to them towards third parties, as well as on its own behalf exercises public law liabilities related to these elements, and liabilities resulting from administrative decisions. The Agency also inherited the liabilities of ppgr, what is to be considered an exception to the principle voiced in the Civil Code that state-owned legal persons are not responsible for the liabilities of the State Treasury. Thus the Act on management of agricultural land owned by the State Treasury, being a unique legal instrument, modifies the ruling of art. $40 \S 1$ of the Civil Code. The Agency is only a trust institution of the State Treasury, an institution which is the administrator of the right the State Treasury is entitled to. In no way is the Agency entitled to property rights in relation to property entrusted to 
it, whereas the State Treasury in no way ceases to hold ownership of the property entrusted to the Agency. However, one has to assume that the Agency is entitled, in relation to the property entrusted to it, to any and all rights listed in art. 140 of the Civil Code. The activity of the Agency as trustee constitutes, in a sense, a statutory specification of tasks of the administrative body that the Ministry of Agriculture and Rural Development is. However, describing the Agency as a unique state-owned legal person seems most appropriate, a state-owned legal person executing statutory and public administration tasks, including appointed to it public administration functions. Executing the tasks imposed on it by the legislators, the Agency not only makes use of civil law, but also of administrative law mechanisms. 